\title{
Virology Experts in the Boundary Zone Between Science, Policy and the Public: A Biographical Analysis
}

\author{
Erwin van Rijswoud
}

Published online: 28 May 2010

(C) The Author(s) 2010. This article is published with open access at Springerlink.com

\begin{abstract}
This article aims to open up the biographical black box of three experts working in the boundary zone between science, policy and public debate. A biographical-narrative approach is used to analyse the roles played by the virologists Albert Osterhaus, Roel Coutinho and Jaap Goudsmit in policy and public debate. These figures were among the few leading virologists visibly active in the Netherlands during the revival of infectious diseases in the 1980s. Osterhaus and Coutinho in particular are still the key figures today, as demonstrated during the outbreak of novel influenza A (H1N1). This article studies the various political and communicative challenges and dilemmas encountered by these three virologists, and discusses the way in which, strategically or not, they handled those challenges and dilemmas during the various stages of the field's recent history. Important in this respect is their pursuit of a public role that is both effective and credible. We will conclude with a reflection on the H1N1 pandemic, and the historical and biographical ties between emerging governance arrangements and the experts involved in the development of such arrangements.
\end{abstract}

Keywords Experts - Virology · Policy development - Public communication · Biographical-narrative method

\section{Introduction}

With the recent outbreak of novel influenza A (H1N1), better known as swine flu, familiar faces became even more familiar. In the Netherlands, the experts who not only frequently informed the public and investigated the virus, but also predicted the

\footnotetext{
E. van Rijswoud ( ()

Institute for Science, Innovation and Society (ISIS), Radboud University Nijmegen, P.O. Box 9010, 6500 GL Nijmegen, The Netherlands

e-mail: e.vanrijswoud@science.ru.nl
} 
pandemic's course and handled public health policy problems, were figures that had assumed this role ever since the 'revival' of infectious diseases in the late 1970s and early 1980s. The general public, politicians, journalists and sceptics alike were already familiar with their names and faces, reputations and views, and even with their tactics and styles of handling such affairs.

This article is about these actors. I have studied the way in which three Dutch virologists, Albert Osterhaus, Roel Coutinho and Jaap Goudsmit, became both prominent and visible experts, and how they dealt with the various challenges entailed by such a role. This article uses a biographical-narrative approach to analyse their advancement into public and policy experts on infectious diseases, against the backdrop of the broader developments in Dutch policy and society.

In this article, the genesis of the visible expert (visible for policymakers, the media and the general public) is studied on an individual or micro-level by examining a number of stages between the late 1970s and the present day. Although textual sources (media coverage, policy reports and so on) are used as a backdrop and frame of reference, the basic source of input for my study is a series of narrative interviews with the experts themselves. Before turning to the case study as such, I will outline the theoretical and methodological framework of my research. I will also place biographical research in the broader field of science studies and discuss the methodological opportunities and risks involved in such an approach.

\section{Looking at and Acting on the Science-Policy-Public Boundaries}

In science studies the science-policy nexus has been extensively studied by looking at boundary organisations (viz. Jasanoff 1990; Guston 1999; Bijker et al. 2009; Huitema and Turnhout 2009), at the role of experts in policy development (Rutgers and Mentzel 1999; Nowotny 2000; Hoppe 2005, 2009; Turnhout et al. 2008) and at policy cultures, or their absence (Hellström 2000; Halffman and Hoppe 2005; Halffman 2005). In this context, a biographical approach has two major advantages. First of all, a biographical approach allows us to study the individual views of the experts themselves and the assessments of their own roles. Secondly, a biographical approach allows us to flesh out the relationship between experts, policymaking and public communication.

The views of experts working in close interaction with policymaking and the public sphere have been extensively studied. Hoppe, for instance, described the views of scientific experts as boundary workers, and discerned several ways of looking at the science-policy boundary (Hoppe 2009). Huitema and Turnhout (2009) focus on the institutional level and describe the 'political' roles of experts working in a Dutch boundary organisation. Claire Waterton (2005) also focused on the science-politics boundary, in particular in the field of research policy and funding. Together with Sarah Davies (2008), who describes the views held by scientists regarding the science-public boundary, these authors analyse the outlooks of individual scientists working across the boundaries of their organisations and disciplines. One of the challenges of discussing the views of scientists in the science-policy and science-public zones is to point out how each of the experts 
acted in these boundary zones and how they negotiated tensions within these zones, creating an identity for themselves in the process.

In light of the 'Third Wave' debate on expertise (see Collins and Evans 2002; Collins and Evans 2007; Wynne 1992, 2003), a distinction can be made between a 'relational' versus a 'realistic' view on expertise. In this paper we will look at the experts and their expertise from a relational or social role perspective (Collins and Evans 2007, p. 2). We treat the role of experts not as a given solid state, but as something in flux. This flux is the net result of interactions between the actions of individuals, and the attributing of trust and credibility by others (viz. Goffman 1959, pp. 15-16; Wynne 1992, p. 282; Huitema and Turnhout 2009, p. 579), turning the experts into 'hybrid characters' (Daston and Sibum 2003). A role in this understanding cannot be attributed solely to what the individual expert wants. Roles are contingent outcomes of these interactions, in which trust and credibility play a crucial part.

This article studies these interactions under specific circumstances, i.e. during moments of crisis. Crises as focusing events challenge experts to inform and comment on the crisis, to assist in the development of appropriate policies, and more generally to sketch the prospects of where the crisis is heading (Birkland 1997). Understood as such, we will see how crises function as springboards for experts from relative invisibility to visibility, and how experts are thus invited or forced to develop their own style of crisis management. Some authors point to the strategic use of crises in inducing policy change (Kingdon 1995; Birkland 1997; Weingart et al. 2000). These sources demonstrate that a crisis is not something that 'just happens' to experts, but that experts, as policy entrepreneurs, also shape and give voice to crises. They tend to use moments of crises to 'capture attention for their causes', at times even by 'overselling to the media' (Weingart 1999, p. 159; see also Edwards 1999, p. 169).

In the expert narratives we will see how perceptions of science, policy and public boundaries, and strategic ways of acting on the boundaries, are viewed from a biographical perspective. This shows the developments, the challenges and crises that experts engage with, and the learning experiences of 'being an expert'. It opens up the biographical 'black box' of experts in policymaking and public debate.

\section{A Biographical-Narrative Approach: Narratives in Action}

The biographical-narrative approach has been gaining ground in the areas of science studies and social sciences (Shortland and Yeo 1996; Huisman et al. 2000; Plummer 2001). We find examples of this approach in anthropological laboratory studies (Traweek 1988), feminist studies of science (Abir-Am and Outram 1987), the sociology of science (Zuckerman 1977; Goodell 1977; Kissmann 2007), the history of science (Porter 2006; Nye 2006; Terrall 2006) and the epistemology of science (Zwart 2008). The biographical-narrative method used here combines socialhistorical studies and narrative analysis, and provides an idiographic view on expertise in the form of 'expert narratives'. To produce these narratives, data from various types and sources were ordered around a specific 'plot' or thematic thread 
(Polkinghorne 2005, p. 69): the advancement of virologists from laboratory experts into experts on policy and the public domain.

The inductive development of narratives involved four iterative stages. In the first stage, data were collected on the academic and public track records of the three virologists, and on the socio-historical context of infectious diseases in which these virologists were situated. This was used to prepare biographical-narrative interviews, ${ }^{1}$ the second step. These interviews focused on their experiences in policymaking and public debate. The experts also commented on each other in these interviews. The third step was to organise the data temporally, hereby focusing on the diachronic data (data on events, their relations and the effects of events). This step included the collection of additional data, for example by conducting a second round of interviews. In the final stage, the expert careers were written down as coherent and empirically-grounded narratives, thereby 'explicating an intrinsically meaningful form' (Polkinghorne 2005, p. 93).

Rather than being the only true reconstruction of past experiences and events, the narratives constitute one possible approach to ordering them coherently. The labels used to structure these narratives must likewise be seen as provisional headings. As to the methodological validity of the narratives that emerge in this manner, it is important to see that the production process of narratives takes place on various levels. The first level is the level of the actual events as experienced by the experts involved, the so-called lived story (Rosenthal 2005, p. 27; Wengraf 2000). Subsequently the experts themselves will reflect on these events retrospectively and from a certain distance. This level can be referred to as the told story. Finally, as a result of the interactions, post hoc reflections and reframings between interviewee and researcher, ${ }^{2}$ the written story as a third level of narrative emerges ${ }^{3}$ (Littig 2008, par. 17). Thus, the written story builds on the two previous levels, and care is taken to secure the internal validity through iterative data collecting and interview sessions, as is also the case here.

Moreover, the written story also feeds back into the previous levels and shapes the lived story. Narrating is a way of constructing ones identity (Brockmeier and Carbaugh 2001, p. 15; Bruner 2001, pp. 34-35). In the course of constructing a 'front region' narrative, the identities the virologists assume as experts shape their actions and interventions, allowing them to present themselves in a way they find desirable (Goffman 1959). Narratives not only constrain, they also enable action (Deuten and Rip 2000, p. 72). By being involved in narrative processes in biographical-narrative interviews, and by intervening in the identity constructions, one actually comes closer to the lived story.

\footnotetext{
1 Interviews with experts or elites differ remarkably from other kinds of interviews; for a brief discussion see Beate Littig (2008).

${ }^{2}$ In this paper I unfortunately cannot illustrate this dimension with a structural analysis of the narratives. For reasons of space I therefore limit myself to a thematic analysis (see Riessman 2008, chapters 3-4).

3 The virologists themselves also produce written narratives on their roles, creating fascinating comparative research material on narrativity and identity (see Goudsmit 2009; Coutinho 2 February 2010).
} 


\section{Dutch Cultures of Expertise}

Before turning to the actual expert narratives, I will give a brief overview of the main Dutch institutes and their functions, the institutional landscape as it were. The Ministries of Health and of Agriculture are the two major policymaking bodies in the domain of infectious diseases, while local (Gemeentelijke Gezondheidsdiensten, GGD) and national (Rijksinstituut voor Volksgezondheid en Milieu, RIVM) public health institutes have an executive task. University Medical Centres (UMCs) play a more independent role. A central advisory body is the Dutch Health Council (Gezondheidsraad, GR). The Health Council is an advisory body that presents the 'state of affairs' of science, and explicitly advises policy, it does not make it (Interview Knottnerus \& De Visser. 30 January 2006; Bijker et al. 2009). In 2005, the Centre for Infectious Disease Control was established as a specialised body for scientific advice and outbreak control, emerging as a new boundary organisation in the Dutch institutional landscape (CIDC, see Ministry of Health 7 December 2004). The Dutch advisory sector for infectious diseases can thus be characterised as a 'corporatist policy arrangement', with a restricted and formally accredited set of experts that act on personal title (Halffman and Hoppe 2005, p. 137; Bijker et al. 2009, pp. 85-86). On an international level we find the European Scientific Working Group on Influenza (ESWI), the European Centre for Disease Prevention and Control (ECDC) and of course the World Health Organization (WHO).

This landscape constitutes the backdrop for the three biographical narratives. Osterhaus started his career as a veterinarian at the RIVM (1978) and went to Rotterdam UMC in 1994. Coutinho worked at the Amsterdam GGD from 1977 until 2005, after which he moved to the CIDC. He has always been affiliated with the Amsterdam Medical Centre (AMC). Goudsmit also spent much of his career at the AMC; in 2002 he joined Crucell, a Dutch biotech vaccine company.

\section{Stages of Crisis and Control}

In discussing the expert narratives, we divide the field of virology into a number of stages. Roughly, we identify five stages, based on the alternation of times of crisis and of control.

1. Late 1970s: The end of infectious diseases: controlling the known enemies

2. 1982-1993: First crisis in virology

3. 1993-1997: Reaching relative stability: controlling the current crisis

4. 1997-2003: Second crisis in virology

5. 2003-April 2009 ${ }^{4}$ : Anticipating future crises

Towards the end of the 1970s, infectious diseases were a dull field of science, on the verge of extinction in a world that knew soap and sewers, vaccines and

\footnotetext{
$\overline{4}$ This study ends just before the novel influenza A (H1N1) pandemic, to which we will turn in the conclusion.
} 
antibiotics. Research into virology consisted by and large of fundamental research into viral oncology where public stakes were low (Van der Noordaa 7 May 2008).

Then, all of a sudden in 1982, HIV/Aids emerged as an unknown enemy in the Dutch gay scene. It constituted a challenge and problem for human virology, accompanied by a sudden influx of research funding, public concern and policy development. ${ }^{5}$ Furthermore, there was an aggressive viral outbreak in seals in the North and Baltic Seas around 1988, which killed tens of thousands of seals. BSE was seen just before this, putting veterinary virology firmly on the map and introducing virologists into the midst of political and public debate. As it turned out, these crises were a springboard to visibility for the three virologists studied here.

At the start of the 1990s, these crises had more or less been brought under control. The causal agents were discovered and the era saw the development and implementation of policies in routine veterinary and human healthcare practices. The HIV/Aids epidemic stabilised in the Netherlands and government interest in infectious diseases decreased. This stability would last until 1997, when new infectious threats suddenly emerged. For the virologists this was a moment to once again assume visibility in public debate and involvement in policy development. The first H5N1 deaths marked the advent of a second crisis. Besides fears of an avian influenza pandemic, scientists and politicians were concerned about the growing threat of bioterrorism and outbreaks of foot and mouth disease. Finally, the outbreak of SARS in 2003 came as a complete surprise. It was SARS that highlighted the real danger of pandemic outbreaks, but that also triggered the awareness of preparedness and prevention plans as new instruments in preventing a pandemic from developing to its full capacity (Osterhaus 6 March 2009).

\section{Stage 1: Late 1970s: Controlling the Known Enemies}

Towards the end of this period of declining public and political need for virologists, all three virology experts completed their studies. Their careers were to become heavily intertwined with the events that followed; they had positioned themselves in such a way that, unaware of future challenges, their involvement with policy and the media during the first crisis was evident.

\section{Stage 2: 1982-1993: First Crisis in Virology}

\section{Ab Osterhaus: The Strategic Scientist}

Although Osterhaus had been in the media since 1978 (on the death of dogs at the world dog show), his story really begins in 1985 with Bovine Spongiform Encephalitis (BSE). In the early years, no one believed BSE could become a human pathogen;

\footnotetext{
5 Of course, the use of the name HIV/Aids here is ahistorical since many other names and abbreviations circulated in the early years, see Shilts (1987). The First Dutch HIV/Aids death was reported in the spring of 1982 (see also Mooij 2004; Andere tijden 26 November 2002).
} 
'people said it was just scrapie' (Osterhaus 6 March 2008). ${ }^{6}$ However, Osterhaus suspected it could indeed become a human pathogen, and in 1988 he pursued it to the EU policymaking arena with backing from his director. As chairman of the EEC Scientific Veterinary Committee he acted cautiously. Nevertheless, he met with scepticism, since pointing out the possible public health dangers went against the grain of policymakers. He did not refrain from setting policy machinery in motion, and a proposal for legislation on the various dangers of BSE was issued almost monthly. In his opinion, this had its effect on policy processes (Osterhaus 29 July 2008).

In 1988, he became more visible to the general public with the dramatic death of seals in the North Sea. ${ }^{7}$ Osterhaus was called in to investigate these deaths, and discovered that the seals had died of a previously unknown virus. However, Greenpeace opposed his conclusion: they were convinced that pollution or poisonous algae had caused the fatalities, since this fitted their own objectives. This disagreement with the environmentalists challenged Osterhaus to prove he was right, and he conducted extensive experiments with seals. To his surprise these studies did identify pollution as a contributing factor in the seals' deaths, but as an indirect causal factor: it made them less resistant. Osterhaus considered this a success: he had discredited his own hypothesis and discovered a causal chain more nuanced than either he himself or Greenpeace had expected (Osterhaus 6 March 2008). The research on seal death, that started in 1985 and has continued ever since, has had an enormous impact on several aspects of Osterhaus' career. It delivered him his first four Nature publications in 1988 and 1989, and many other papers followed. His reputation grew, and the conflict with Greenpeace pulled him into political and public debates. Due to the seal death research he also became scientific advisor to a national seal shelter.

The controversies surrounding BSE and the seal deaths show two aspects of Osterhaus' role. He was self-confident in his estimations about risks, but also acknowledged criticism from his sceptics. The tricky question was when to stick to his original position, and when to adopt the opposing view, and, consequently, the appropriate strategy. This, he says, created a tension: on the one hand he had his own gut feelings, and at the same time he tried to think through competing viewpoints. There was not only an epistemological choice to be made, but also a balancing act to carry out: considering various interests and health threats. We will characterise his role as that of the strategic scientist: someone who carefully balances different viewpoints and forms of evidence, but who also has the strategic skills and will to further his own case.

\section{Roel Coutinho: From Critical to Controversial Collaborator}

Of the three virologists studied here, Coutinho's role was the one shaped the most by the nature of his research and the positions he held. As a public health director in

\footnotetext{
${ }^{6}$ All translations of interview quotes and quotes from Dutch newspapers were made by the author, and where possible corrected for errors.

7 He often tells this story. I heard it during a master class he gave (29 November 2007), and newspaper articles often mention it. The master class also showed how he weaves science and personal narratives together into one story.
} 
Amsterdam with expertise in viral epidemiology and professional relations with homosexuals and intravenous drug users, it was obvious he would be involved in dealing with HIV/Aids, and he was very motivated to do so.

In 1984, Coutinho, Goudsmit and their superior, Jan van der Noordaa, initiated the Amsterdam Cohort Studies (ACS) ${ }^{8}$ on HIV/AIDS, and began testing a cohort of homosexual men. The results were alarming: $30 \%$ of the participating 750 homosexuals were infected with HIV, revealing an urgent public health issue. However, as homosexuals were in a process of emancipation, they feared discrimination and blame for bringing HIV/Aids into the world. Disease prevention did not outweigh this concern. Since Coutinho saw that both homosexuals and drug users tended not to take the danger of infection seriously (as they had previously done with venereal diseases), he used the statistics to make them aware of the scale and nature of the epidemic. His rationale was that without being open about a problem, one cannot start solving it. Also, covering up the truth implies a disdain for society and is likely to result in a loss of credibility (Coutinho 13 May 2008; Mooij 2004; Andere tijden 26 November 2002).

Although a sound approach for Coutinho, it met with substantial opposition on various fronts. Indeed, the slightest hint towards the identification of homosexuals as a risk group made them revolt; and to Coutinho's dismay the national government gave equal weight to the control of HIV and the prevention of discrimination. A chasm emerged between scientific and socio-political realities, ${ }^{9}$ but one that could be handled within the National Committee on AIDS Control (NCAB) to which he belonged. ${ }^{10}$

If the scientists were taken by surprise by the HIV/Aids epidemic, then the media were even more so. They desperately needed information, and Coutinho and other members of the NCAB were in a position to virtually control the coverage of HIV/ Aids (Mooij 2004, p. 21). By doing so they also influenced policy (Coutinho 13 May 2008), since politics, especially in those days, was very susceptible to public opinion.

Despite this chasm, in the beginning he perceived and experienced the collaboration with homosexuals as 'extremely good, very constructive and also very useful' (Coutinho 25 July 2008). But tensions increased as time progressed: HIV/Aids spread, the number of parties involved increased and the decision-making structure grew more complex. From 1986 onwards, when a new information campaign was launched, Coutinho's critical, factual, and open attitude was too problematic for those working with him; he openly stated that the campaign masked the fact that homosexuals were a distinct risk population (Coutinho 25 July 2008). Following this criticism, the productive working relationship with the gay community started to crumble.

On two occasions in 1989 the tensions between Coutinho, homosexuals and politics culminated in conflict. A clash with politics came when the Secretary of

\footnotetext{
8 Still ongoing, see http://www.amsterdamcohortstudies.org/ (accessed 8 Dec 2009).

9 This chasm was not uniquely Dutch, but a feature of the early HIV/Aids years in all countries.

10 Since 1987: National Committee on AIDS Control. The change from 'coordinating' to 'controlling' HIV/Aids is a remarkable one, airing an increased demand for control over the epidemic.
} 
State for Health rejected a report on anonymous HIV testing. Coutinho, one of its authors, openly mocked the Secretary and he was brought to account. Although this was an unpleasant experience, Coutinho said he would do the same again (Coutinho 13 May 2008). And so he did. Later that year he was appointed professor, and in his inaugural lecture he surprised friend and foe by again criticising the HIV/Aids communication policy of the NCAB. Members of the NCAB and of the gay community were outraged: how could someone like Coutinho threaten the societal position of homosexual men? Coutinho was forced to step down from the NCAB.

But how dramatic was his departure? The information campaigns were up and running (if not without some hiccups), a policy framework was in place and 'personal relations were fine' (Coutinho 25 July 2008); he actually felt relieved to be out of the NCAB.

Coutinho's role during this stage started out as critical collaborator, and it shifted to controversial collaborator after 1986: he was very outspoken, stubborn, did not negotiate with others on the contributions he made to the media, and he did not let himself be tamed by the sensitivities of gay emancipation. He described this period as being jammed between science and policy. ${ }^{11}$ The collaboration in the control of HIV/Aids became gradually more problematic, which resulted in this shift in Coutinho's role.

\section{Jaap Goudsmit: The Hubristic Expert}

Goudsmit's role contrasts those of Coutinho and Osterhaus. He was not heavily involved in the development of health policy frameworks or legislation, as his sphere of activity was more limited to public debates. These debates included the debate on gay blood donors and on the origins of AIDS. When invited to reflect on the 1980s during interviews, he did not recount specific moments, but rather gave a general impression of his contacts with the media. What dominated was the sense of losing control over his utterances in the media, and this had a lasting influence on Goudsmit's attitude towards the media (Goudsmit 2 April 2008).

One event in the expert development of Jaap Goudsmit, which gradually takes us to the end of the second stage, is an affair that shocked many: the Buck-Goudsmit affair. $^{12}$ Early in 1990 Henk Buck, a professor of chemistry, wanted to check whether a DNA drug he had discovered could work on HIV. Goudsmit therefore ran tests with the substance, and mistakenly confirmed that it worked. A letter was sent to Science and Buck and Goudsmit held an official press conference. This was, after all, a discovery of great importance.

The positive atmosphere turned bleak when Buck started making claims that went beyond the original significance of the discovery, promising a cure within a few years. People were outraged, since HIV/Aids patients were given false hope. While Buck himself was scapegoated, Goudsmit got away, but not entirely untouched. The drama affected him, and he became more reluctant when called on as an expert and more cautious when in contact with the media (Goudsmit 2 April

\footnotetext{
11 Every time he spoke about this, he made a wrenching gesture with his hands.

12 See (Hagendijk and Meeus 1993; Eijgenraam 1991; Andere tijden 29 November 2005).
} 
2008). Despite criticism of his role in the controversy, Goudsmit kept his position at the AMC; and when three years later Science announced him as Europe's most important HIV/Aids researcher (Cohen 1993) the Buck-Goudsmit affair was not mentioned at all.

During the second interview Goudsmit described his 1980s self as a hubristic expert (Goudsmit 19 May 2008), and other sources support that view: someone who is very confident about his knowledge base. This stage of his career involves frequent loss of control over statements and quotes: being tempted by journalists to utter sweeping statements and daring analyses. Analysing the interviews with Goudsmit, we find two interrelated problems for the hubristic expert. The first is a lack of experience in controlling the media; the second is a lack of knowledge of the limits to his expertise. As we will see, a gradual shift in both these aspects later in his career would change his role.

\section{Stage 3: 1993-1997: Reaching Relative Stability: Controlling the Current Crisis}

In 1993, some 10 years after the first Dutch cases of HIV/Aids, the epidemic stabilised, a partial indication that the expert community had gained relative control over the situation. The general implications were that HIV/Aids became less newsworthy, which of course had implications for the roles of the scientific experts, in particular Roel Coutinho. Transformation is a recurring theme in this third stage: positions, whether in a political, institutional, public or epistemological sense, changed, and the role of our experts changed accordingly.

\section{Ab Osterhaus: The Prophet of Doom}

Osterhaus experienced a number of changes that were to make him even more visible than before. An important change in this respect is that of occupational context. In 1994, he left the RIVM, 'the institute that muzzled him' (Osterhaus 29 July 2008), when he refused to end his seal research (NRC Handelsblad 14 April 2003). He and his staff moved to the Erasmus Medical Centre in Rotterdam, where he still holds a position.

This change from a muzzling institute to a university that was not familiar with 'ministerial responsibility' liberated him in his role as public expert; and with this change a second came along: he became director of the WHO National Influenza Centre. Influenza appeared on his radar screen and Osterhaus became interested in past influenza pandemics. He then became chairman of the European Scientific Working group on Influenza, the ESWI. On a more personal note, being struck by influenza himself made him experience the severity of flu. These personal, professional and scientific experiences with flu would from now on become a dominant factor in his contact with policy and the media (Osterhaus 29 July 2008). In 1995, he made some initial, cautious remarks that hinted at the lurking threat of influenza (Trouw 17 February 1995). But in 1997 the cautiousness gave way to a 
much more alarming message when the first human bird flu casualty was reported (Osterhaus 6 March 2008). Osterhaus and others wrote a letter to Nature entitled $A$ Pandemic Warning (De Jong et al. 1997), in which they referred to H5N1 as a virus with 'unknown pandemic potential'. A few months later he would be more straightforward in a Dutch newspaper, saying that 'a future pandemic flu on the scale of the 1918 Spanish Flu was not unimaginable' (Algemeen Dagblad 30 December 1997).

The flu deaths were to trigger the second crisis in the recent history of virology. In contrast to the first crisis, when the virologists were taken by surprise, Osterhaus became the advocate of awareness of and preparation for influenza. From now on, a discursive strategy announcing the coming pandemic was aired in public media and in policymaking, using the pandemic warning as an instrument to create awareness and a policy forum (Parool 26 April 2001). This led to the charge from politicians and colleagues of being a prophet of doom (Osterhaus 6 March 2008), which marks the role he had during this stage.

\section{Roel Coutinho: An Expert's Hibernation}

Although not of his own bidding, Coutinho's preoccupation with policymaking and the media decreased significantly after 1992. A quite visible expert began to hibernate. He felt content with these developments since he had become worn out with endless debates in committees and with telling the same stories to the media over and over again. Expert hibernation in this sense does not mean he was entirely absent in the media or in policymaking, but compared to the preceding and following periods there was a significant decrease of exposure. There is one event, however, which demonstrates his view as an expert on health problems. After a decline in HIV/Aids cases in 1993, he later reported the epidemic to be far from over, and stated how he thought the problem should be prevented: 'It makes a huge difference when you get the problem out in the open' (Trouw 5 December 1998). This strategy was put to the test during the 1980s, and it passed. He says that it has been the key to his expert policy and still is today.

\section{Jaap Goudsmit: Vaccine Research Taming the Hubris}

Goudsmit's role also changed during this stage. Although at the end of the second stage he was recovering from the Buck-Goudsmit affair, in retrospect he claims the whole affair did not fundamentally change his ideas on how to be an expert.

The two processes that we identified earlier-learning to control the media and becoming more aware of his knowledge base-are drawn to a close at the mid1990s by the realities of vaccine research. In 1990, Goudsmit and Osterhaus received funding to develop a candidate HIV vaccine. In 1992, the former was very confident about the prospects for such a vaccine (Trouw 24 March 1992); but just two years later we see a mixed attitude: Goudsmit is still optimistic regarding the possibilities of a vaccine, although he thinks that it will require international coordination and prolonged collaboration (Parool 26 March 1994). That is what he 
therefore endeavours: in 1994, Goudsmit becomes a co-founder of the IAVI, the International Aids Vaccine Initiative. In the meantime, the joint project with Osterhaus fails, in part because they 'entirely underestimated the difficulties in developing a vaccine' (Goudsmit in Mooij 2004, p. 164). Goudsmit is currently still active in the development of vaccines, but his prospects for an HIV vaccine are sombre (NRC Handelsblad 1 December 2007; Goudsmit 19 May 2008). In Goudsmit's own words, the hubristic expert discovered that he was not that knowledgeable at all, that despite all his knowledge about HIV he could not produce a vaccine. This is what in effect changed the way in which he performs as an expert in public. As he became painfully aware of the limits of his expertise, Goudsmit changed into an expert who wants to be in strict control of what to say, when, where and to whom (Goudsmit 2 April 2008).

\section{Stage 4: 1997-2003: Second Crisis in Virology}

It was during this stage that Osterhaus incited awareness of a potential pandemic. He became a key figure in the Dutch, European and WHO pandemic preparedness plans, and he aired his pandemic warning ever more frequently and urgently, acting as a catalyst for policymakers. But other threats, such as the threat of bioterrorism (Gezondheidsraad 2001, 2002), foot and mouth, and later SARS, were also posing challenges for virologists. The greatest fears were, and still are, zoonoses: animal viruses that evolve into human pathogens (Gezondheidsraad 2005). Collectively, this amounted to the second crisis.

\section{Ab Osterhaus: The Entangled Expert}

Following the H5N1 deaths in 1997, Osterhaus unfolded a scenario that matched his earlier response to BSE. Virologists, including Osterhaus, urged the WHO to develop pandemic preparedness plans, which was done instantly. In an individual capacity, he then initiated a meeting to discuss the appropriate policy responses for Europe. Besides him initiating the meeting, it is interesting to see how he organised this meeting and steered its outcomes.

Osterhaus was a well-known and respected figure in the European health policy scene, belonging to some of the key scientific or health care committees. A first move he made when organising the 1998 meeting was to hand it over to an EU civil servant, now the meeting's captain. The civil servant would take credit for this meeting, and it would also be political. The second move was to select the participants, including the responsible EU commissioner and a range of influential virologists. By selecting the participants himself, Osterhaus brought together a specific body of political power and scientific expertise; and he managed to orchestrate the political process in a direction he deemed optimal without drawing attention to himself. Osterhaus strategically translated his pandemic warning into an official and visible EU committee. 
From then on, a discursive strategy in the media invoked a coming crisis: 'We have had three pandemic outbreaks of influenza, in 1918, 1957 and 1968, killing some 100 million civilians. We can be sure a new pandemic will arrive, and unless we take appropriate measures, hundreds of thousands will die'. Although the pandemic warning was a policy lubricant (Parool 26 April 2001), Osterhaus believed in the reality of this message and he says it was a plain technical assessment (Osterhaus 6 March 2008). His colleagues, however, believed the message to be an overstatement, bordering on lobbying for research funds (Coutinho 13 May 2008; Goudsmit 2 April 2008, 19 May 2008; Van der Noordaa 7 May 2008). They also say that Osterhaus' tone has tempered over the years, perhaps because the discursive strategy has had its desired effects, perhaps because the scientific reality has changed. ${ }^{13}$

This tension between his own scientific gut feeling and the scepticism of his critics is a dilemma he dubbed the 'cry wolf dilemma'. This 'visionary virologist' had to perform a balancing act between two extremes: on the one hand the credible but reticent academic, on the other hand the 'incredible fool' (Osterhaus 6 March 2008); and the longer it took for a pandemic to strike, the more his credibility would be at stake.

His public appearances became numerous as the concerns over bioterrorism, influenza, bird flu and SARS increased, and as the Dutch government neglected public communication. The media's solution to this latter problem was straightforward: call Osterhaus. He is always willing to spare a moment since he believes science communication is part of a scientist's professional ethos (Osterhaus 6 March 2008). These appearances amounted to a clear media policy with a handful of tricks to safeguard his public credibility.

It was not only the media who sought his assistance. In the midst of the BSE outbreak of 2000, Osterhaus was also asked to personally advise the Minister of Agriculture, who appeared to be ill-informed by his own staff. That same afternoon, the minister informed Parliament of his BSE policy. Osterhaus heard the same sentences he had spoken that morning, and in the interview says he felt relieved: 'Democracy was still able to function as it should' (Osterhaus 6 March 2008). Civil servants lack the expertise to make informed decisions and they need experts to give advice, even if that means importing their political agenda.

2003 was a busy year for virology, but especially for Osterhaus. In addition to his professorship and his extensive policy work, both avian flu and SARS struck in the spring of that year. He became involved in both of them. One moment that Osterhaus especially recalls regarding avian flu is a meeting of the Outbreak Management Team (OMT) to determine the necessary policy. The majority opposed Osterhaus' policy view, and rather than conforming, he tried to enforce his view by threatening them with a minority point of view, sketching what might happen should the OMT abstain from following his advice. It proved effective, but also demonstrated the fragility of his position: had he not been there, policy would have been very different (Osterhaus 6 March 2008).

\footnotetext{
13 This was before the H1N1 pandemic; the pandemic warning gained force with H1N1.
} 
When SARS struck, the pandemic preparedness plans came into effect. Under the direction of the WHO a small selection of laboratories, including Osterhaus' own lab in Rotterdam, were on the hunt for the cause; and on 16 April 2003 the Osterhaus lab managed to find the final and most rewarding piece of the puzzle. A press meeting was held at the WHO Geneva headquarters that same afternoon; a letter in Nature (Fouchier et al. 2003) and a royal decoration followed. Osterhaus reaped the rewards for the discovery and his status rose (Enserink 2003). But what is more: the WHO prevented a pandemic. This marks the SARS crisis as a moment when virologists could control a crisis. Osterhaus himself noticed that his credibility, authority and power in science, politics and society rocketed.

However, the various cases he narrated illustrate the strategic position Osterhaus held, a position that slowly became problematic. The many 'hats' he wore and responsibilities he carried, both nationally and internationally, confounded his expert role. He says it was manageable to know when to speak from which position and responsibility, but outsiders saw this same person in quite different settings, taking up both scientific and political roles in one same interview (see for example Netwerk 21 February 2003). Other virologists noted that he was doing the government's dirty work (Osterhaus 29 July 2008; Goudsmit in NRC Handelsblad 5 July 2003), and even a ministerial letter to parliament had to justify the way Osterhaus' view was accommodated in policy (Veerman 23-04-2003). In the second crisis, Osterhaus had scientific credibility and political responsibilities, he made scientific and strategic statements, and he spoke in both a personal and collective capacity, making him an entangled expert.

\section{Roel Coutinho: A Technical Spokesman}

The hibernation of Coutinho lasted until 2000, when after more than 20 years at the public health division of the Amsterdam GGD, Coutinho became scientific director of the entire institute. In his new position his role as expert changed. HIV/Aids was still on his agenda, as were venereal diseases in general, but as the second crisis called for experts to master a wide array of human and veterinary infectious agents, he also had to inform the public on a broad portfolio of diseases. The number of public appearances increased dramatically, and he once again became a familiar figure in the newspapers. ${ }^{14}$ This increasing diversity of topics was welcomed, but it also implied challenges, as he now had to keep track of all kinds of developments and topics that went beyond his original expertise (Coutinho 25 July 2008).

How did he cope with this? In really complex cases, Coutinho says, he referred the journalist to a knowledgeable colleague. But in most other cases, Coutinho did it himself. He read up on the subject matter, called a few people, and then appeared in the media to comment or inform. The major challenge was to decide when he felt knowledgeable enough not to consult others. We note that this back region (Goffman 1959), the preparation, remains invisible to the public view; that which is visible in the front region is the knowledgeable expert, who then takes the credit.

\footnotetext{
${ }^{14}$ Between 1992 and 2000 LexisNexis reports 21 articles for Coutinho; between 2000 and 2008, an equal time frame, there were 96.
} 
The role he takes up is that of spokesperson and translator: speaking on behalf of the institute, and translating the specialist expertise residing there to public or political contexts (Coutinho 13 May 2008). There are a number of reasons to do so. First of all, he believes that it is part of his responsibility to carry the risks involved here. Secondly, he is the experienced expert, aware of the intricacies of communication. Thirdly, he enjoys communicating with the media, and this is stimulated by the many successes he has experienced (Coutinho 13 May 2008). Consequently, he is again a familiar face in the media. As the topics have become far less controversial and political than they were during the $1980 \mathrm{~s}$, the contributions to policy and to the public sphere are also more technical (determining risks, developing preparedness plans). This makes him a technical spokesman.

\section{Jaap Goudsmit: The Puritan}

In the fourth stage we see several changes affecting Goudsmit's expert role. During the mid 1990s, he held a full professorship at the Amsterdam Medical Centre, and the IAVI was a side project. After 2002 the balance started to shift. He moved to biotech firm Crucell in 2002, where he is now director of research and member of the board. He ended his board membership of the IAVI in 2004, and he swapped his full professorship for an honorary one.

In addition to the professional changes, as a virologist he became more cautious and reserved regarding what he knew. From studying his narrative, we see that 'taking control', that lesson from the 1980s and 1990s, is accomplished at two levels: on the communicative level by knowing when to stop talking, and on the strategic level by choosing the right battlefields. It is his habit of selecting the more regulated battlefields that is a very distinct feature of his expert career after the mid1990s (Goudsmit 2 April 2008). He chooses spaces he feels comfortable and secure in, spaces that respect the strict boundaries of his expertise. Although these factors are important in understanding why Goudsmit takes up a certain role, in practice the different constituents are difficult to discern.

Two loci where he prefers to act are the courtroom and the study, writing popular science books. In a long laudation on his experiences as a courtroom expert, ${ }^{15}$ he describes it as the site where expertise is used in the 'purest way possible' outside of science, where all agendas lie open and only the expert's knowledge is questioned. The courtroom enhances the separation of facts and their interpretation; the juridical boundaries create a regulated environment, which is appreciated by Goudsmit (Goudsmit 2 April 2008).

Another preferred site for showing his expertise is his writing desk, where he is in charge of the content and form. Since the turning point in his expert biography in the mid-1990s, a steady stream of popular science books has been published. He tries to communicate technical knowledge to the public in the purest possible way, although this has not been well received by either book reviewers or editors, who say his

\footnotetext{
15 It is not clear exactly how often he has been in court as an expert witness. Court case reports place him in court between 2001 and 2007.
} 
books are too technical, too hard to read, or promise more than they actually contain (Goudsmit 19 May 2008; Trouw 17 June 2000, 1 March 2003).

Next to these 'battlefields' that are cherished for their safety, Goudsmit avoids policymaking, for he loathes the conflicts of interest and the consensus finding. He has developed a love of purity in expertise that excludes policy rooms. Because of his love of purity, the preference for a clear expert role and the resulting choices, we refer to him as the puritan.

\section{Stage 5: 2003-April 2009: Anticipating Future Crises}

\section{Pushing Through the Fifth Stage: Concerted Action for Control}

Following years of a pandemic warning, the rapid spread of SARS, and numerous actual or possible outbreaks, politicians in the Netherlands were well aware that the lack of political responsibility, coordination, and strategic planning for outbreaks needed to be addressed. Furthermore, in 2003 a veterinarian died after being infected with bird flu. ${ }^{16}$ This focusing event (Birkland 1997) triggered the shift to the fifth stage, during which there were endeavours to increase control over the viral threats. What is remarkable about this shift is that although the virologists occupied different positions and held different views on the science-policy-public nexus, they pushed it through collectively.

Goudsmit chose to write an open letter to a Dutch newspaper with the provocative title 'The Netherlands are unprepared for a viral attack'. The message was that the government was failing to take responsibility for the control of epidemics and public communication; people like Osterhaus were doing what the government should have been doing (NRC Handelsblad 5 July 2003). The Director-General of the Ministry of Public Health replied, in which he acknowledged part of the critique (NRC Handelsblad 17 July 2003). Osterhaus and Coutinho also campaigned for a new infectious disease infrastructure, referring to SARS and avian flu as the wake-up calls. Osterhaus continued his alarming predictions of a pandemic, and even Coutinho made dramatic statements to create awareness (Volkskrant 5 June 2003), which is contrary to his factitious style of communicating. It was, in his words, steering between the Scylla of a failing outbreak management and the Charybdis of creating a panic (Coutinho 25 July 2008).

The collective efforts proved effective: in the course of 2004, a decision was taken to install the Centre for Infectious Disease Control (CIDC) at the RIVM, a centre that, under political accountability, would coordinate outbreaks of infectious diseases and handle public communication (Ministry of Health 7 December 2004). This new instrument for control embodies the fifth stage.

\footnotetext{
16 There was even a television documentary made about the death of the vet, featuring both Goudsmit and Osterhaus. Zembla, 2 October 2003.
} 


\section{Ab Osterhaus: The Seemingly Invincible}

When the government planned the CIDC in 2004, Osterhaus was officially consulted regarding these plans and asked to stand as candidate director. Alarmed by the fact that the government would set up the centre without proper consultation with the Health Council, Osterhaus informed them of this and suggested a consulting committee. The next step was the selection of a director. Osterhaus turned the offer down, as he had had his share of the RIVM in the past. In his view, the only other person capable of the job was Coutinho, and Osterhaus personally phoned him (Osterhaus 29 July 2008); Coutinho accepted. Again, Osterhaus was tying a policy process and its outcome together by using formal and informal relations and his credibility in policy; this, again, took place in the back region.

The implication of the CIDC was that the political complexity surrounding Osterhaus was temporarily resolved, and that there was a government voice for public communication. Meanwhile, Osterhaus' campaign for more pandemic vigilance continued. Starting in 1997, major steps were taken in this direction, such as the national storage of antiviral drugs (Gezondheidsraad 2005).

Osterhaus' role in avian flu and in the successes regarding SARS resulted in a dramatic increase in public, political and scientific credibility. Through his countless media appearances he gained the status of a public figure, and some even call him 'the David Beckham of virology' (Volkskrant 10 February 2009). He seems to be an invincible expert, not just because of this increase in credibility, but also because the risks of entanglement had been resolved. But as the H1N1 pandemic demonstrated, 'David Beckhams' are particularly prone to loss of credibility; there was great upheaval with regard to Osterhaus' commercial, scientific and political interests (Enserink 2009).

\section{Roel Coutinho: Directing a New Boundary Organisation}

Coutinho has been director of the CIDC since January 2005 and his main responsibility has been to set up a new control structure for infectious diseases. Zoonoses are by far the greatest threat, and there is considerable conflict between the interests of agriculture (a melting pot for infectious agents) and of public health. Notorious cases are MRSA and Q fever bacteria (Coutinho 25 July 2008). Coutinho is caught in the middle of both ministries, and acts as a kind of buffer. Whenever there is an outbreak, Coutinho and his centre are on top of it, with regard both to outbreak management and to public communication. The CIDC has the data, the expertise and the responsibility to do so. He is still a spokesman and translator, but now under ministerial responsibility.

Coutinho's role has led to a dispute between Coutinho and Osterhaus. Coutinho describes himself as an expert who is independent of the institutional setting and always does what he believes in. Osterhaus, however, depicts Coutinho as a governmental expert, since he falls under direct responsibility of the health minister. Osterhaus recounts how he has seen Coutinho change over the years, becoming less outspoken, and says that his political accountability has contributed to this 
(Osterhaus 29 July 2008). Although Coutinho clearly experiences the political pressures, he says it has not changed him; he is not the governmental representative Osterhaus claims he is. He is less outspoken, since there is no need for him to act otherwise (Coutinho 13 May 2008).

The debate of his role is illustrative for the embedding of the CIDC as a new 'boundary object' in the Dutch institutional landscape, combining science, policy and communication in a novel way.

\section{Jaap Goudsmit: Hobby Expert}

Following his interventions in infectious disease control in 2003, Goudsmit repeated the same strategy in 2004. In the same form and in the same newspaper, he castigated the Dutch education policy and pleaded for a dual university system (NRC Handelsblad 10 June 2004). This was not based on his expertise as a virologist, but on his experience in academia and in industry. Again, this letter evoked much response, some of it critical, and a documentary (Tegenlicht 5 February 2006) and book essay followed (Goudsmit 2006).

In addition to this interest in education, he is still writing popular science books on virology. This is probably the only topic in which he still publicly discusses his expertise in virology. He is constantly experimenting with form, and in his present book he is again trying to communicate pure knowledge, which remains difficult. The resulting book is Dromen van vaccines ('Dreaming of vaccines', Goudsmit 2009).

The puritan expert keeps the hubris on a leash, and Goudsmit is very selective in his expert dealings. He nevertheless displays what he calls his 'hobbies' (Goudsmit 2 April 2008): writing novels and sharing his views on issues he feels knowledgeable about. This combination of a strict expert acting within virology and a hobbyist outside of virology leads to the role of hobby expert.

\section{Conclusion: On Opening Up the Biographical Black Box}

This article has studied from a biographical-narrative perspective how Albert Osterhaus, Roel Coutinho and Jaap Goudsmit positioned themselves over the years as policy and public experts in the field of infectious diseases. Their narratives covered five stages, from the late 1970s until April 2009, when the swine flu pandemic struck. Right from the start, they were all simultaneously conducting research, drafting public health or veterinary policy based on that research, and communicating to various publics and patient groups on the diseases. In some cases, communication was used strategically to induce policy change (Birkland 1997; Kingdon 1995), but often enough communication was aimed at solely informing the public on the status quo of outbreaks.

Of the various elements of the experts' biographies, two aspects stand out from the rest: the personal reflections of these experts on their roles; and the tandem development of governance arrangements and the role of these virologists therein. 
To start with the first: the biographical approach shows us how the early, trial and error methods of 'being an expert' steadfastly developed into more crystallised views on their roles. The experts based their methods on the early-career understandings of the relationship between science, politics and the public domain. This article opens up the biographical-narrative 'black box' of these experts, and the enactment of that biography in practice (Goffman 1959; Deuten and Rip 2000; Brockmeier and Carbaugh 2001). Learning experiences, personal or communal reflections on specific events, the continuous process of re-narrating and reframing past experiences, all added up to an individual conviction on 'how to perform as a credible expert'. In Coutinho's case, we might say that his self-perception as an expert has not changed dramatically, but solidified in a repertoire of communicating the facts. Goudsmit, on the other hand, following a redefinition of his expertise, radically changed the way in which perceived his role in policy and in public debate. Then we have Osterhaus, who still finds himself in a continuous balancing act between a credible scientist, a policy entrepreneur, a public communicator and an industry advisor. The biographical-narrative approach has elucidated how each of them have accommodated themselves in the boundary zone between science, policy and public debate, and thus juxtaposes with a more macro-sociological understanding of expertise, such as Nowotny's 'narrative of expertise' (Nowotny 2000).

The second aspect that stands out is the development of governance arrangements. The studies of Coutinho and Osterhaus demonstrate that since they were pioneers in the development of new governance arrangements, they remained central figures in these arrangements for infectious disease control. The emerging governance structures and the pioneering virologists remained tied together. It is no accident that when the CIDC was being set up, Osterhaus and Coutinho were the prime, if not only, candidate directors. Up until the H1N1 pandemic, these two virologists were the key figures in policymaking and public debate. In cases where new governance arrangements emerge, we can thus expect the leading figures in that process to remain tied to those arrangements. It is certainly relevant to scrutinise the degree in which the experts themselves strive to remain tied, whether the arrangements as such keep them tied, and why. This article demonstrates how the involvement of certain figures is understandable from a historical and biographical perspective.

However, with shifting challenges and changing social, economic and political contexts, it may be desirable to renew the composition of expertise in governance arrangements. Without wishing to pass direct judgment on either Coutinho or Osterhaus, I suggest that biographical ties should not grant access by default. Probing these dimensions, as this study does, assists in the assessment of the nature and structure of contemporary governance arrangements, the persons involved and their relationships to science, politics and the public sphere. Although this does not provide a prescriptive approach to expertise, such as that suggested by Collins and Evans (Collins and Evans 2007), it may help to critically question the almost automatic policy involvement of some experts.

The recent H1N1 pandemic demonstrates that this problematisation is not merely a scholarly exercise. From the first announcements of the new virus, Osterhaus and Coutinho dominated politics and the media. Their performances raised a plethora of 
comments and questions and, to put it mildly, were not undisputed (Van Rijswoud 2009). This led to the organisation of a public debate with Osterhaus and Coutinho, inviting them to publicly reflect on their roles (see Dortmans and Van Rijswoud 2009).

A last and important conclusion of this case study is that during the recent pandemic, the historically grown roles of Osterhaus and Coutinho did not resonate with the changing ideas of various public domains on the roles of experts. As norms and expectations for credibility and authority change over time, these experts cannot rely on the crystallised understandings of their roles and their settled positions in governance arrangements. During the course of the pandemic, for various reasons, Osterhaus' and Coutinho's credibilities were severely damaged and their authorities disputed. Osterhaus' balancing act could not withstand the growing wave of criticism (Enserink 2009), and Coutinho's notion of medical authority was challenged down to the bone (Coutinho 2 February 2010). These controversies raise a call for a more thorough reflection on their roles, both within governance and public communication. Answering that call, this article tells us, is a continuous struggle and challenge.

Acknowledgments I would like to thank Hub Zwart, Hans Marks, Willem Halffman and the two anonymous referees for their critical yet constructive comments. I am indebted to Ab Osterhaus, Roel Coutinho and Jaap Goudsmit for their willingness to contribute to this study.

Open Access This article is distributed under the terms of the Creative Commons Attribution Noncommercial License which permits any noncommercial use, distribution, and reproduction in any medium, provided the original author(s) and source are credited.

\section{References}

Abir-Am, Pnina, and Dorina Outram. 1987. Uneasy careers and intimate lives: Women in science (1789-1979). New Brunswick \& London: Rutgers State University.

Algemeen Dagblad. 'Hongkong, da's een end weg' [Hong Kong, that's far far away], 30 Dec. 1997, 3. Andere tijden. Aids bereikt Nederland [Aids reaches The Netherlands], 26 Nov. 2002.

Andere tijden. Buck [Buck], 29 Nov. 2005.

Bijker, Wiebe E., Roland Bal, and Ruud Hendriks. 2009. The paradox of scientific authority: The role of scientific advice in democracies. Cambridge, MA: MIT press.

Birkland, Thomas A. 1997. After disaster: Agenda setting, public policy and focusing events. Washington, DC: Georgetown University Press.

Brockmeier, Jens, and Donal Carbaugh, eds. 2001. Narrative and identity: Studies in autobiography, self and culture. Amsterdam/Philadelphia: John Benjamins Publishing Company.

Bruner, Jerome. 2001. Self-making and world-making. In Narrative and identity: Studies in autobiography, self and culture, ed. J. Brockmeier and D. Carbaugh. Amsterdam/Philadelphia: John Benjamins Publishing Company.

Cohen, Jon. 1993. Flying Dutchman: Jaap Goudsmit. Science 260: 1263.

Collins, H.M., and Robert Evans. 2002. The third wave of science studies: Studies of expertise and experience. Social Studies of Science 32 (2): 235-296.

Collins, Harry M., and Rob Evans. 2007. Rethinking expertise. Chicago: Chicago University Press.

Coutinho, Roel. 2 February 2010. Het gezag van de wetenschap in gedrang [Scientific authority is under pressure] (Machiavelli lezing).

Daston, Lorraine, and H. Otto Sibum. 2003. Introduction: Scientific personae and their histories. Science in Context 16 (1/2): 1-8. 
Davies, Sarah R. 2008. Constructing communication: Talking to scientists about talking to the public. Science Communication 29 (4): 413-434.

De Goeij, Hans. 2003. Nederland bewust van epidemiegevaar [The Netherlands are aware of flu danger]. NRC Handelsblad, July 17: 11.

De Jong, J.C., E.C.J. Claas, A.D.M.E. Osterhaus, R.G. Webster, and W.L. Lim. 1997. A pandemic warning? Nature 389: 554.

Deuten, Jasper J., and Arie Rip. 2000. Narrative infrastructures in production creation processes. Organization 7 (1): 69-93.

Dortmans, Koen, and Erwin Van Rijswoud. 2009. Machinerie van experts [Machinery of experts]. LEV 2: 6-9.

Edwards, Arthur. 1999. Scientific expertise and policy-making: The intermediary role of the public sphere. Science and Public Policy 26 (3): 163-170.

Eijgenraam, Felix. 1991. Dutch AIDS researchers feel heat of publicity. Science 260: 1422.

Enserink, Martin. 2003. The virus collector. Science 300: 1228-1229.

Enserink, Martin. 2009. In Holland, the public face of flu takes a hit. Science 326: 350-351.

Fouchier, Ron, Thijs Kuiken, Martin Schutten, Geert Van Amerongen, Gerard Van Doornum, Bernadette Van den Hoogen, Malik Peiris, Wilina Lim, Klaus Stöhr, and Albert Osterhaus. 2003. Koch's postulates fulfilled for SARS virus. Nature 423: 240.

Gezondheidsraad. 2001. Defence against bioterrorism. The Hague: Health Council of the Netherlands.

Gezondheidsraad. 2002. Bioterrorism: Follow-up report. The Hague: Health Council of the Netherlands.

Gezondheidsraad. 2005. Use of antiviral agents and other measures in an influenza pandemic. The Hague: Health Council of the Netherlands.

Goffman, Erving. 1959. The presentation of self in everyday life. New York: Anchor Books.

Goodell, Rae. 1977. The visible scientists. Little, Brown: Boston.

Goudsmit, Jaap. 2003. Nederland niet voorbereid op virusaanval [The Netherlands are unprepared for a viral attack]. NRC Handelsblad, July 5: 7.

Goudmist, Jaap. 2004. Richt de Royal Dutch University op [Erect a Royal Dutch University]. NRC Handelsblad, June 10: 8.

Goudsmit, Jaap. 2006. Tegen de vlakte. Amsterdam \& Antwerpen: Uitgeverij Augustus.

Goudsmit, Jaap. 2009. Dromen van vaccins: dertig jaar op zoek naar de juiste reactie. Amsterdam/ Antwerpen: Uitgeverij Contact.

Guston, David H. 1999. Stabilizing the boundary between US politics and science: The role of the office of technology transfer as a boundary organization. Social Studies of Science 29 (1): 87-111.

Hagendijk, Rob, and Jan Meeus. 1993. Blind faith: Fact, fiction and fraud in public controversy over science. Public Understanding of Science 2 (Nr. 4): 391-415.

Halffman, Willem. 2005. Science-policy boundaries: National styles? Science and Public Policy 32 (6): 457-467.

Halffman, Willem, and Rob Hoppe. 2005. Science/policy boundaries: A changing division of labour in Dutch expert policy advice. In Democratization of expertise?, eds. S. Maasen and P. Weingart. Dordrecht: Springer.

Hellström, Thomas. 2000. Technoscientific expertise and the significance of policy cultures. Technology in Society 22: 499-512.

Hoppe, Rob. 2005. Rethinking the science-policy nexus: From knowledge utilization and science and technology studies to types of boundary arrangements. Poiesis \& Praxis 3: 199-215.

Hoppe, Rob. 2009. Scientific advice and public policy: Expert advisers' and policymakers' discourses on boundary work. Poiesis \& Praxis 6 (3-4): 235-263.

Huisman, Frank, Catrien Santing, and Bert Theunissen eds. 2000. De biografie als genre in de wetenschapsgeschiedenis. Gewina (special issue) 23: 1-90.

Huitema, Dave, and Esther Turnhout. 2009. Working at the science-policy interface: A discursive analysis of boundary work at the Netherlands Environmental Assessment Agency. Environmental Politics 18 (4): 576-594.

Jasanoff, Sheila. 1990. The fifth branch: Science advisers as policymakers. Cambridge, MA: Harvard University Press.

Kingdon, John W. 1995. Agendas, alternatives and public policies. New York: Harper Collins College Publishers.

Kissmann, Ulrike Tikvah. 2007. Normalizing moral dilemmas: The construction of true and false experts in German nuclear technology. Science as Culture 16 (2): 187-205. 
Littig, Beate. 2008. Interviews mit Eliten-Interviews mit ExpertInnen: Gibt es Unterschiede? Forum Qualitative Sozialforschung 9 (3): 37. (paragraphes).

Ministry of Health, Welfare and Sports. 2004. Instellingsbesluit Bestuurlijk afstemmingsoverleg infectieziektebestrijding. Staatscourant 236: 10.

Mooij, Annet. 2004. Geen Paniek: HIV/Aids in Nederland (1982-2004). Amsterdam: Uitgeverij Bert Bakker.

Netwerk. Vrees voor gevaarlijk griepgolf [Fear for a dangerous flu epidemic], 21 Feb. 2003.

Nowotny, Helga. 2000. Transgressive competence: The narrative of expertise. European Journal of Social Theory 3 (1): 5-21.

NRC Handelsblad. Goed voor 23 ziekteverwekkende virussen [The score: 23 pathogenic viruses], 14 Apr. 2003, 2.

NRC Handelsblad. Niets stopt aids [Nothing stops Aids], 1 Dec. 2007, 7.

Nye, Mary. 2006. Scientific biography: History of science by another means? ISIS 97: 322-329.

Parool. Banaan als betaalbaar aids-vaccin [Banana as cheap Aids vaccine], 26 Mar. 1994, 21.

Parool. Virussen zullen komende jaren dodelijk toeslaan [Viruses will strike a lethal blow], 26 Apr. $2001,3$.

Plummer, Kenneth. 2001. Documents of life 2: An invitation to a critical humanism. London: Sage Publications.

Polkinghorne, Donald E. 2005. Narrative configuration in qualitative analysis. In Biographical research methods, ed. R. Miller. London: Sage.

Porter, Theodore M. 2006. Is the life of the scientist a scientific unit? ISIS 97: 314-321.

Riessman, Catherine Kohler. 2008. Narrative methods for the human sciences. Thousand Oaks: Sage.

Rosenthal, Gabriela. 2005. Biographical Research. In Biographical research methods, ed. R. Miller. London: Sage.

Rutgers, M.R., and M.A. Mentzel. 1999. Scientific expertise and public policy: Resolving paradoxes. Science and Public Policy 26 (3): 146-150.

Shilts, Randy. 1987. And the band played on: Politics, people and the AIDS epidemic. Harmondsworth: Penguin.

Shortland, Michael, and Richard Yeo, eds. 1996. Telling lives in science: Essays on scientific biography. Cambridge: Cambridge University press.

Tegenlicht. No time for losers, 5 Feb. 2006.

Terrall, Mary. 2006. Biography as a cultural history of science. ISIS 97: 306-313.

Traweek, Sharon. 1988. Beamtimes and Lifetimes. Cambridge, Massachusetts: Harvard University Press. Trouw. Bij de lus te pakken [Got it by the loop], 24 Mar. 1992, 15.

Trouw. Griep slaat dit jaar over: rampscenario ligt klaar [Flu skips a year: preparedness plans are ready], 17 Feb. 1995.

Trouw. 'Het gevaar van aids is nog lang niet geweken' ['The Aids-menace is still there'], 5 Dec. $1998,8$.

Trouw. Jaap Goudsmit tevergeefs op zoek naar aidsvirus in Egypte [In vain, Jaap Goudsmit travels Egypt to find the Aids virtus], 17 June 2000, 36.

Trouw. De allerkleinste en gemeenste [The tiniest and the meanest], 1 Mar. 2003, 40.

Turnhout, Esther, Matthijs Hisschemöller, and Herman Eijsackers. 2008. Science in Wadden Sea policy: From accommodation to advocacy. Environmental Science \& Policy 11: 227-239.

Van Rijswoud, Erwin. 2009. Flu: Weighing up conflicting expert information. Nature 460: 571.

Veerman, Cees. 2003. Letter to parliament: Stand van zaken Aviaire Influenza, ed. F. a. F. Department of Agriculture.

Volkskrant. Virologen: Nederland sluit ogen voor gevaar epidemie [Virologists say Holland ignores risks of epidemic], 5 June 2003, 2.

Volkskrant. De David Beckham van de virologie [Virology's David Beckham], 10 Feb. 2009, 2.

Waterton, Claire. 2005. Scientists' boundary work: Scientists' conceptions of the boundaries between own research and policy. Science and Public Policy 32 (6): 435-444.

Weingart, Peter. 1999. Scientific expertise and political accountability: Paradoxes of science in politics. Science and Public Policy 26 (3): 151-161.

Weingart, Peter, Anita Engels, and Petra Pansegrau. 2000. Risks of communication: Discourses on climate change in science, politics and the mass media. Public Understanding of Science 9: 261283.

Wengraf, Tom. 2000. Uncovering the general from within the particular: From contingencies to typologies in the understanding of cases. In The turn to biographical methods in social science: Comparative issues and examples, eds. P. Chamberlayne, J. Bornat, and T. Wengraf. London: Routledge. 
Wynne, Brian. 1992. Misunderstood misunderstanding: Social identities and the public uptake of science. Public Understanding of Science 1: 281-304.

Wynne, Brian. 2003. Seasick on the Third Wave? Subverting the Hegemony of Propositionalism: Response to Collins and Evans (2002). Social Studies of Science 33 (3): 401-417.

Zuckerman, Harriet. 1977. Scientific elite: Nobel laureates in the United States. New York: Free Press.

Zwart, Hub. 2008. Understanding the human genome project: A biographical approach. New Genetics and Society 27 (4): 353-376.

\section{Interviews}

Roel Coutinho: 13 May 2008; 25 July 2008.

Jaap Goudsmit: 2 April 2008; 19 May 2008.

André Knottnerus \& Marianne de Visser (President \& Vice President of the Health Council): 30 January 2006.

Jan van der Noordaa (Emeritus Professor of Virology): 7 May 2008.

Albert Osterhaus: 6 March 2008; 29 July 2008. 